\title{
VISST er det vanskelig
}

\section{Innledning}

I løpet av mange år med undervisning i norsk som fremmedspråk, har jeg ofte støtt på spørsmål som: Er det vanskelig å lære seg norsk; Ligner det mest på tysk eller engelsk; Hva er egentlig vanskelig i norsk grammatikk? Visst er det vanskelig, svarer jeg, like vanskelig som alle andre språk. Hva slags utfordringer en må streve med, varierer jo naturligvis. Den norske journalisten Per Egil Hegge, som blant annet er kjent for sin språkspalte i Aftenposten, skrev i en av sine sarkastiske kommentarene: «Utlendinger som skal loere norsk, bør få loerere som kan holde balansen: Det er ingen grunn til å underslå at dette er et vanskelig språk. Samtidig bør pedagogene ikke legge så stor vekt på akkurat det at elevene mister motet før de er kommet skikkelig i gang.» ${ }^{1}$

Betyr det kanskje at vi nødvendigvis ikke må følge de grammatiske reglene så nøye? Eller bedre sagt: Betyr det kanskje at vi ikke nødvendigvis må følge de grammatiske reglene så nøye?

Hegge mener vel at alle språk er vanskelige å lære godt, særlig når det gjelder små språklige finesser. Setningsstruktur, ordstilling for eksempel kan ofte by på vanskeligheter på norsk. I spørsmålene jeg stilte ovenfor, har vi ulike ordstillinger, og begge to er riktige, men uttrykkene betyr ikke det samme. I den første setningen, når man sier at vi nødvendigvis ikke må gjøre sånn og sånn, snakker vi om at det ikke kan være slik, altså at vi ikke må følge de grammatiske reglene så nøye, mens i det andre tilfellet mener taleren at det ikke nødvendigvis er sikkert at vi alltid må holde oss så nøye til reglene.

Ordenes plassering spiller også en viktig rolle når vi undersøker betydningen, funksjonen for enkelte småord, som for eksempel visst (Jfr. Vaskó, 2012). Det er visst ikke så enkelt. Språket vi bruker, gjenspeiler måten vi tenker på, måten vi forholder oss til det som blir sagt, på hvilket grunnlag våre påstander baseres på, hvor vi har fått informasjonen fra, osv. I denne artikkelen skal jeg se nærmere på de forskjellige fortolkningsmulighetene ved bruken av trykklett visst og den leksikalske tvetydigheten som betegner partikkelens bruksmåter.

\footnotetext{
${ }^{1}$ http://tux.aftenposten.no/spraak/spraak?action=question \&id=5180
} 


\section{Partikkelen visst}

Uttrykket «Det er sikkert og visst» er jo kjent fra bl.a. folkeeventyrene. Men hvor sikker kan den være som bruker denne frasen? I Språknytt (4/1997) kan vi lese følgende: «Hvis vi ... hører utsagnet ... «Det er sikkert og visst», kan vi lett få følelsen av at det vi hører, er en slags besvergelse - egentlig er det en diger løgn vi har hørt, men fortelleren bedyrer at det er sannheten, og det selv om det virker som en meget usannsynlig sannhet.» ${ }^{2}$

I den dansknorske perioden kodet ordet vis(s) en leksikalsk betydning av «sikkerhet» (jfr. Falk og Torp, 1992). Bruken av forsterkeren visst er en åpenbar bevaring av den opprinnelige betydningen. Det er ikke helt uvanlig at et ord indikerer temmelig forskjellige betydninger i ulike språklige omgivelser når de går gjennom en grammatikaliseringsprosess. Utviklingen av visst som partikkel viser kanskje den neste etappen i grammatikaliseringen. Partikler kommer vanligvis sist i denne prosessen. Ord og uttrykk som koder primært noe bestemt, kan gjerne utvikle en pragmatisk funksjon som indikerer det motsatte av den opprinnelige meningen (jfr.1).

(1) Han blir sikkert mer interessert etter hvert.

Det som kommuniseres i (1), er ikke det at avsenderen er sikker, snarere tvert imot. Avsenderen er i tvil om vedkommende kommer til å bli interessert, om han kommer til å bry seg om faget $\mathrm{i}$ det hele tatt. Adverbet signaliserer avsenderens holdning - en liten oppmuntring - som ikke er i overensstemmelse med ordets leksikalske betydning.

Partikkelen visst indikerer talerens holdning til utsagnsinnholdet. Ifølge Borthen og Knudsen koder visst at taleren «er blitt gjort oppmerksom på det som beskrives $i$ ytringen, via sannsynlig evidens for dette» (Jfr. Borthen og Knudsen 2014, 404). Avsenderen tar ikke ansvar for proposisjonens sannhet. $\mathrm{Hun}^{3}$ indikerer at ytringen innebærer noe som hun selv ikke har full kontroll over. Den signaliserer en viss usikkerhet ettersom avsenderen mangler kunnskap til å bedømme sin egen uttalelses sannhet. Med visst kommuniserer avsenderen en beskjed til mottakeren at så vidt hun vet eller har hørt, så skal proposisjonen være sann.

\footnotetext{
${ }^{2}$ http://www.sprakradet.no/Vi-og-

vart/Publikasjoner/Spraaknytt/Arkivet/Spraaknytt_1997/Spraaknytt_1997_4/Smaastoff/

${ }^{3}$ Jeg skal heretter referere til avsenderen som «hun» og mottakeren som «han».
} 
Vi kan skjelne mellom to bruksområder av visst som pragmatisk partikkel, to forskjellige grunner som gjør avsenderen usikker.

Visst indikerer avsenderens usikkerhet når det gjelder hennes slutning som er bygget på hennes sanseinntrykk. Utsagnet beskriver talerens observasjoner og visst belyser at avsenderen trekker en slutning på grunnlag av sine sanseevner (jfr.2).

(2) Enda en gang har jeg plukket søppel etter andre ved Ulfsbakk. Det er visst noen, ja kanskje flere, som tror at noen har som jobb å plukke sammen søppelet etter andre. $^{4}$

Avsender trekker seg fra ansvaret for påstanden, likevel antyder den harmdirrende skribenten i leserinnlegget at etter hennes beste viten fins det folk som legger masse søppel etter seg. Visst i (2) dekker egentlig to forskjellige funksjoner. På den ene siden uttaler avsenderen seg om en tidligere observasjon; hun har sett søppelet. På den andre side markerer visst at avsenderen ikke tør å stole på sin egen hukommelse. Det virker som om hun hadde sett søppelet, men ville ikke gå god for proposisjonens gyldighet, dvs. ville ikke tro sine egne øyne. Det er mulig å få fram disse funksjonene tydeligere, atskilt fra hverandre, men likevel ligger alltid avsenderens observasjon som angir premissen, til grunn.

Bygget på den premissen, kan avsenderen trekke sin slutning, som er ganske tilbakeholdende (jfr.3,4).

(3) Hos oss har en av dem vært innbruddsforsøk. Det er visst ikke uvanlig på nybygde anlegg der rutiner og sikring ikke er på plass ennå. ${ }^{5}$

(4) Jeg har visst ikke takket ordentlig for at du gav meg lammesteken din.

I (3) er det tidligere erfaring eller annenhåndsinformasjon vi har med å gjøre. Vedkommende skal ha hørt om innbruddsforsøk i boligsameie som er i en oppstartfase. I (4) derimot indikerer visst at avsenderens observasjon reaktiviserte noen minner i hennes hukommelse. I begge tilfeller demper visst påstanden og signaliserer at avsenderen tar avstand fra proposisjonsinnholdet, fordi hun har trukket konklusjon ut fra usikre premisser. Dersom avsenderen ikke har direkte mulighet til å verifrisere det beskrevne saksforhold ved egen observasjon, har fått informasjonen fra andre kilder, eller har hørt eller lest et utsagn om den

\footnotetext{
${ }^{4}$ http://www.op.no/nyheter/noen-tror-visst-det-er-andres-jobb-a-plukke-opp-soppel-etter-dem/s/1-857346810 10. mai 2014, kl. 10:49

${ }^{5}$ http://www.vaktmesterandersen.no/referanser/det-oppleves-nesten-som-vi-har-en-fulltidsansattvaktmester/
} 
situasjonen det refereres til, kan avsenderen ikke være helt sikker på om proposisjonen er sann. I dette tilfelle markerer visst annenhåndsinformasjon (jfr.5).

(5) «... så han var nødt å tjene ekstra penger til svigerinnen og hennes fire barn, hvorav minst to av dem hadde astma, fikk jeg inntrykk av, og faren deres, altså broren til ham jeg snakket med, satt visst inne for noe småtteri, men han skulle sitte lenge og det gjorde inntrykk på meg, kan du tenke deg,...» (Loe, 86)

I (5) gjør avsenderen oppmerksom på at den informasjonen hun kommuniserer, ikke er noe hun har førstehåndskunnskap om. Ved å vise til en kilde kan avsenderen implisere at hun ikke ønsker å presisere hvor informasjonen egentlig stammer fra. Partikler som indikerer annenhåndsinformasjon er ofte betegnet som «hearsay»-partikler i litteraturen (jfr.bl.a. Palmer, 1986).

Visst skiller seg fra andre partikler $\mathrm{i}$ den forstand at den ikke signaliserer avsenderens subjektive oppfatning, men refererer enten til en objektiv observasjon som gjør avsenderen i stand til å trekke en slutning eller den refererer til en annen informasjonskilde (jfr. Fretheim, 1981).

Blass (1990) foreslår at såkalte «hearsay»-partikler helst bør betraktes som markører av fortolkende språkbruk (Sperber \& Wilson, 1986). I sin analyse av partikkelen «ré» i sissala viste det seg at i de tilfeller hvor et leksem ikke bare fungerer som «hearsay»-partikkel, men også forekommer i andre konstruksjoner, gir denne analysen en mer omfattende forståelse av partikkelen.

Den norske partikkelen visst viser seg å ha minst to funksjoner som de ovennevnte eksemplene antyder (jfr. 2-5), men visst kan betraktes som «hearsay»-partikkel bare i den ene rollen. Derimot kan man hevde generelt om visst at ved hjelp av partikkelen signaliserer avsenderen sin fortolkning av forutgående iakttagelser (jfr.6,7,8).

(6) «Først freste det, så smalt det enda høyere, generatorene skurret mens tonene døde med et surt sukk ....

a. Orgelet er visst ødelagt, sa jeg lavt.

b. Jeg hører det....»

(Lars Saabye Christensen 1997:238)

(7) «Det er visst nesten ingen grense for hva man kan snakke med dem om, så vidt jeg forstår.»

(Loe:45) 
Det er visst mange som blir forvirret av dette.

På grunnlag av objektive observasjoner (jfr.6), egen hukommelse (jfr.7) eller informasjon fra andre kilder (jfr.8) trekker avsenderen en viss slutning og indikerer samtidig et forbehold når det gjelder proposisjonens sannhetsverdi. Ifølge relevansteorien kan en ytring brukes deskriptivt for å beskrive et saksforhold eller interpretativt for å beskrive en annen ytring eller tankegang som den ligner på. Vi snakker om interpretativ språkbruk når en ytring eller en tanke er brukt til å representere en annen tanke eller ytring, og avsenderens tolkning av mottakerens tanker, og disse to ligner på hverandre innholdsmessig. Avsenderens mål er ikke å gå god for sannheten av proposisjonen ytringen inneholder, men å utføre en korrekt gjengivelse av den opprinnelige tankegangen. Likevel må vi være oppmerksom på at graden av likhet mellom to tanker eller ytringer kan variere, men proposisjonene i disse ytringene må ha samme logiske egenskaper, dvs. samme kontekstuelle implikasjoner.

Vi har med fortolkende språkbruk å gjøre når en ytring blir brukt som et «ekko» av en annen ytring. Avsenderen tilskriver en annen person en tanke og gir ekko av den tanken. Ytringen kan oppnå relevans ved å kommunisere avsenderens holdning til den tanken ytringen gir ekko av. Hvis vi har med ironi å gjøre, er holdningen avvisende, og taleren indikerer at hun har motsatt oppfatning. Vi kan tenke oss for eksempel en situasjon hvor en person lover å tapetsere rommet, men når eieren av huset kommer hjem, er rommet fremdeles i samme tilstand som før. Så kan eieren si (9):

(9) Du har visst jobbet hardt hele dagen.

Ved hjelp av visst uttrykker avsenderen sin mening i (9) at ingenting tyder på at mottakeren har gjort noe som helst med veggen.

Funksjonen til partikkelen visst er å kode avsenderens usikkerhet når det gjelder proposisjonens sannhetsverdi og samtidig rettlede mottakeren i fortolkningen av de tilsiktede kontekstuelle virkningene. Partikkelen har en posedural mening, nemlig å markere at det handler om en gjengivelse av en annen tanke, utsagn eller mangelen på det (jfr.10).

(10) De har visst glemt bursdagen min.

Visst1 og visst3 i eksempel (11) er av samme slag: partikkelen demper utsagnet og indikerer dermed at avsenderen ikke uten videre går god for proposisjonens sannhet. 
Avsenderen har trukket sine slutninger på grunnlag av premisser hun ikke tør stole på. Utsagnene, hvor visst befinner seg, avspeiler informasjon som stammer fra andre kilder eller tidligere observasjoner.

(11) «- I går ikkje rundt med slarv, Randi, men betyr det at 'n ikkje trur, han Yngvar, på Gud?

- Han gjer visst 1 ikkje det, nei.

- Men du da, trur du?

- I? Ja, i tør visst2 ikkje anna, om det no e vane hell kva det e. I ber da kveldsbønn, men stilt, for me sjøl. Men du e visst3 religiøs vorte du, Julie.» (Anne Karin Elstad 1995, 141)

Ytringene visst 1 og visst 3 forekommer i, angår henholdsvis en tredje person eller mottakeren, men den proposisjonen visst 2 står sammen med gjelder selve avsenderen. Vi kan ikke interpretere utsagnet på noen annen måte enn at avsenderen ser seg selv utenfra, dvs. hvordan andre ville oppfatte henne. Visst har på den ene siden den oppgaven å markere at det som avsenderen kommuniserer, egentlig er en fortolkning av andres betraktning. Meningen er ikke tilskrevet en konkret person, men gjengir en generell oppfatning som folk flest har i den lille bygda hvor handlingen foregår. På den andre siden indikerer partikkelen at taleren skriver under på proposisjonsinnholdet. Ved å reflektere en allmenn mening kan avsenderen også distansere seg fra proposisjonsinnholdet (jfr.12).

(12) A: At det går an å ha ørepynt i øyenbrynet!

$B$ : Det er visst den nye moten.

Avsenderens mål, å gi en korrekt gjengivelse av en tankegang, betyr ikke nødvendigvis at hun vil gi ekko av en proposisjon av et tidligere utsagn, men hun kan ha til hensikt å kommunisere de kontekstuelle implikasjoner av en forutgående ytring (jfr.13).

(13) A: Dag etter dag sitter han foran fjernsynet og ser på fotballkampene.

B: Det irriterer deg visst.

Ytringen får relevans ved å kommunisere avsenderens holdning til den tanken, eller implikaturen ytringen gir ekko av. Visst antyder altså at den proposisjonen partikkelen står sammen med, er en fortolkning av en annen tankegang og markerer talerens innstilling. Dermed blir partikkelen uforenlig med ikke-sannhetsfunksjonelle verb som står etterhengt (jfr.14, 15, 16). 
(14) \#Jørgen er visst skyldig, tenker jeg.

(15) \#Jørgen er visst skyldig, håper jeg.

(16) ?Jørgen er visst skyldig, tror jeg.

Verbalfrasene i høyre-dislokert posisjon uttrykker avsenderens subjektive synspunkt om den forutgående proposisjonen. Visst indikerer derimot avsenderens mangel på kunnskap til å bedømme sannheten i sin egen uttalelse. Som jeg nevnte ovenfor, kan avsenderen gå god for et påstandsinnhold ved å gi ekko av den tankegangen det inneholder. Ikkesannhetsfunksjonelle verb koder også i forskjellig grad av epistemisk stillingtagen fra avsenderens side. «Tro» viser seg å være minst subjektiv: det demper avsenderens holdning til proposisjonen i utsagnet.

\subsection{Visst i interrogative setninger}

Visst forekommer som vanlig i utsagnssetninger, men partikkelen kan også brukes i interrogativer med en spesifikk oppgave (jfr.17).

\section{(17) Har visst Eva vært her før?}

I (17) stiller ikke taleren spørsmål til mottakeren fordi hun ikke kan besvare det. Tvert imot deler avsenderen og mottakeren samme oppfatning, nemlig at Eva ikke har vært her før. Et negativt spørsmål kan forekomme i en samtale med minst tre deltakere: A, B og C. Fretheim (1998) kaller B direkte mottaker og C indirekte mottaker. Hensikten med spørsmålet er å få støtte fra mottakeren ved å vise overfor en indirekte mottaker at den negative bekreftelsen er riktig. A stiller et spørsmål med en forventning om at Bs svar kan skille tretten mellom A og C. Avsenderen henvender seg til mottakeren fordi hun betrakter den informasjonen hun ber om, relevant nok til å avgjøre saken. Det negative svaret beskriver avsenderens mening, og dermed kan vi si at visst markerer en annen tanke også ved et spørsmål. Intonasjonen hjelper mottakeren (mottakerne) å trekke slutningen og utlede avsenderens proposisjonelle holdning. Intonasjonen kan nemlig redusere utsagnets fortolkning ved å instruere mottakeren i hvordan han kan interpretere de kommuniserte antakelser som gjør ytringen relevant (jfr. Fretheim:1998). 


\section{Visst og visstnok}

Visst forekommer i likhet med andre trykklette setningsadverbialer i midtfeltsposisjon eller høyre-dislokert. Plassert etterhengt kan visst få et litt sterkere appellerende særtrekk (jfr.18).

(18) Han som sitter på terrassen, det er Morten, visst.

Man kan oppfatte (18) som en påstand, fortolkning av avsenderens eget sanseinntrykk, like godt som et spørsmål (jfr. Fretheim, 1981).

Vi finner et visst som står i forfeltet, trykktungt og fungerer som forsterker (jfr.19).

(19) Visst skjer det noe en gang iblant.

Adverbet brukes først og fremst for å fokusere på utsagnsinnholdet, peke på en mulig kontrast mellom mottakerens tidligere antagelse og informasjonen ytringen inneholder ved å understreke at proposisjonsinnholdet er sant. Partikkelen i (19') som markerer annenhåndsinformasjon, er et homonym til adverbet visst $\mathrm{i}$ (19).

(19') «Det er visst noe som skjer en gang i blant. Han hadde hørt om det før.» (Loe:148)

Partikkelen visst kan erstattes av visstnok når ordet indikerer at informasjonen kommer fra en annen kilde (jfr.20, 20').

(20) «... opposisjonen har lagt opp til noen skrekkelige spørsmål i spørretimen i morgen,

det er visst noe om Midt-Østen eller Afghanistan eller hva det var, og det gidder jeg rett og slett ikke å være med på.»

(Loe, 117)

(20') «... opposisjonen har lagt opp til noen skrekkelige spørsmål i spørretimen i morgen, det er visstnok noe om Midt-Østen eller Afghanistan eller hva det var, og det gidder jeg rett og slett ikke å være med på.»

Derimot kan ikke avsenderen bruke visstnok når hun vil beskrive et sanseinntrykk (jfr.21, 21'). 
(21) Jeg er visst ikke helt bra.

(21') \# Jeg er visstnok ikke helt bra.

Visst og visstnok koder ikke den samme posedurale mening. Med visst kommuniserer avsenderen at hun ikke er i stand til å vurdere proposisjonens sannhetsverdi, og dermed tar avstand fra den. Visstnok derimot markerer at den slutningen som ytringen inneholder ikke er avsenderens egen konklusjon: hun kan ikke ta ansvar for den, men det finnes en kilde hvor informasjonen er hentet fra. Avsenderens kunngjøring, at det finnes en kilde hvor saksopplysningene stammer fra, fører til at proposisjonens sannhetsverdi ikke blir dempet i en så stor grad sammenliknet med visst Forskjellen kommer klarere fram når visst/visstnok står sammen med den epistemiske bruken av modalverbet «må» (jfr.22, 22').

(22) Han må visst ha gått og lagt seg.

(22') ??Han må visstnok ha gått og lagt seg.

Avsenderens observasjon angir premissene i (22) og (22'), og på grunnlag av disse premissene kan hun trekke en slutning. Modalverbet «må» signaliserer talerens vurdering som neppe er forenlig med funksjonen til visstnok, som viser til en annen kilde.

At visstnok kan forekomme både i forfelt og midtfelt posisjon, med samme funksjon, tyder også på det at ved å bruke visstnok uttrykker avsenderen at sannsynligheten for at proposisjonen skal være sann er ganske stor (jfr. 23,24,25).

(23) Visstnok fikk han lov av Bryggeriforeningen.

(24) «Hun fikk visstnok hjelp av en mann fra kommunen.» (Johnsrud, 37)

(25) «Noe private greier, visstnok.» (Johnsrud, 202)

Når vi har med et deontisk «må» å gjøre, dvs. når modalverbet koder en nødvendighet, kan det stå sammen med både visst og visstnok (jfr. 26, 26').

(26) Det må visst gjøres innen 31 dager.

(26') Det må visstnok gjøres innen 31 dager. 
I svensk kan partikkelen visst forekomme i midtfeltsposisjon både som forsterker og som demper. I (27) forteller avsenderen at hun er meget sikker på at den omtalte personen er over tjue år, dersom visst gis betoning.

(27) Han är visst över tjugo år gammal.

Det er prosodien som avgjør hvilken rolle vi har med å gjøre. Når partikkelen oppstår som forsterker, må den være betont (jfr.28).

Det är han visst. / Visst är han det.

\section{Oppsummering}

Partikkelen visst har som funksjon å indikere at den ytringen som partikkelen forekommer i, brukes interpretativt. Ved hjelp av partikkelen, indikerer avsenderen at hun gir ekko av en annen tankegang. Derfor er den konklusjonen hun har trukket, grunnlagt på usikre premisser. I tillegg til å gi ekko av en tankegang kan avsenderen kommunisere sin holdning til den omtalte tanken. Hun kan uttrykke sin påtegning eller indikere at hun har akkurat den motsatte oppfatning, som for eksempel ved ironi.

Både ved hjelp av visst og visstnok kan avsenderen kommunisere at hun ikke tar ansvar for proposisjonens sannhetsgehalt, men ved bruken av visstnok kan hun tydeliggjøre at utsagnsinnholdet ikke stammer fra avsenderen selv, og er ikke resultat av avsenderens eget resonnement.

\section{Litteraturliste}

Blass, Regina 1990: Relevance Relations in Discourse. A Study with special reference to Sissala. Cambridge: Cambridge University Press.

Borthen, Kaja \& Knudsen, Cecilie S. 2014: Semantiske og pragmatiske aspekter ved trykklett visst. Norsk Lingvistisk Tidsskrift 32(2). 360-411.

Falk, Hjamar \& Torp, Alf 1992: Etymologisk Ordbog over det norske og det danske sprog. Oslo: Bjørn Ringstrøms Antikvariat 
Fretheim, Thorstein 1981: "Ego"-dempere og "alter"-dempere. Maal og Minne Nr. 1-2, 86100.

Fretheim, Thorstein 1991: Formal and Functional Differences between s-Internal and sExternal Modal Particles in Norwegian. Multilingua 10,175-200.

Fretheim, Thorstein 1998: Intonation and the Procedural Encoding of Attributed Thoughts: The case of Norwegian Negative Interrogatives I Rouchota,V. \& Jucker, A.H. (red.) Current Issues in Relevance Theory. Amsterdam: John Benjamins

Palmer, Frank R. 1986: Mood and Modality. Cambridge: Cambridge University Press

Sperber, Dan \& Deirdre Wilson 1986/1995: Relevance. Communication and Cognition. Oxford: Blackwell.

Vaskó, Ildikó 2012: Tenk på det, da gitt! Pragmatikai jelölők a norvég nyelvben. Budapest: Budapester Beiträge zur Germanistik.

\section{Eksempler fra litterære verk:}

Elstad, Anne Karin (1995): Julie

Johnsrud, Ingar (2015): Wienerbrorskapet

Loe, Erlend (2011): Fvonk

Saabye Christensen, Lars (1997): Den misunnelige frisøren 